\title{
Soil-water-plant relationship and fruit yield under partial root-zone drying irrigation on banana crop
}

Eugênio Ferreira Coelho ${ }^{*}\left(\mathbb{D}\right.$, Marcelo Rocha dos Santos ${ }^{2}$, Sérgio Luíz Rodrigues Donato ${ }^{2}$, Jailson Lopes Cruz ${ }^{1}$, Polyanna Mara de Oliveira ${ }^{3}$, Ariane Castricini3 ${ }^{3}$

${ }^{1}$ Embrapa Mandioca e Fruticultura, R. Embrapa, $\mathrm{s} / \mathrm{n}$ 44380-000 - Cruz das Almas, BA - Brasil.

2Instituto Federal Baiano, Campus Guanambi, C.P. 009 46430-000 - Guanambi, BA - Brasil.

${ }^{3}$ Empresa de Pesquisa Agropecuária de Minas Gerais, Rod. MGT 122, km 155 - 39525-000 - Nova Porteirinha, MG Brasil.

${ }^{*}$ Corresponding author <eugenio.coelho@embrapa.br>

Edited by: Mohammad Valipour

Received July 19, 2017

Accepted May 17, 2018
ABSTRACT: Climatic uncertainties have compromised water resources, which influences irrigated agriculture. Irrigation is an important alternative to mitigate the effects of water scarcity. Partial root-zone drying (PRD) is a rational use of irrigation water. This study aimed to evaluate PRD for irrigation management of banana crop, cv BRS Princesa, under semi-arid conditions in Brazil. A field experiment was carried out with five treatments: one control (full irrigation) and four with $50 \%$ reduction of water irrigation depth (WID) and frequencies alternating the side to be irrigated of the plant row of $0,7,14$ and 21 days. Stomatal conductance, growth, yield and soil water status were evaluated. Results indicated that banana crop cv. BRS Princesa shows shoot physiological regulation for $50 \%$ reduction of soil water and vapor pressure deficit between 1.92 and $2.25 \mathrm{kPa}$. Decrease in yields of treatments with WID reduction compared to full irrigation is due to the reduction of root uptake rate, which is related to vapor pressure deficit and soil water availability. Partial root-zone drying saves $50 \%$ of irrigation water and increases water use efficiency of banana cv. BRS Princesa crop by $78 \%$.

Keywords: Musa spp., water use efficiency, vapor pressure deficit, irrigation deficit

\section{Introduction}

Uncertainties of rainfall and increased water consumption have caused significant reduction of available water resources for irrigated crops in Brazil. Thus, investments are necessary in more efficient irrigation systems and water-saving technologies, namely the rational water use by reduction of evaporation and percolation losses as well as irrigation deficit (Fereres and Soriano, 2007). In addition, cultivars that are more tolerant to water deficit need to be researched on (Donato et al., 2015) and techniques for conservation agriculture need to be used, namely mulching, crop rotation and intercropping (Davies et al., 2011).

The partial root-zone drying (PRD) is a feasible irrigation strategy of water management that may save up to $50 \%$ water without significant yield loss. The strategy is based on the reduction of transpiration by plants due to physiological regulation when submitted to PRD or watering (Davies et al., 2011; Dodd, 2009; Sadras, 2009; Kang and Zang, 2004; Kang et al., 2002). Plants can sense and respond to changes in their immediate environment, such as the soil drying process, and then regulate growth and functioning to avoid excessive shoot dehydration stress (Davies et al., 2005). Most studies reported in literature regards the physiological aspects of PRD; however, these aspects result from root-shoot transport. Therefore, root uptake also has to be considered in PRD studies.

Information on the PRD technique for fruit crops in Brazil is limited to mango (Santos et al., 2016; Santos et al., 2015) and lemon (Sampaio et al., 2014). Banana may require between $600 \mathrm{~mm}$ and $1500 \mathrm{~mm}$ of water (Coelho et al., 2015; Robinson and Alberts, 1986) and is cultivated in all irrigated areas of northeastern Brazil, particularly in the North of Minas Gerais State. The region is susceptible to effects of climate change (Sivakumar et al., 2005), such as an increase in annual water deficit. The use of PRD as an irrigation water management strategy may be feasible for the crop and prevent yield loss during drought.

This study evaluated the feasibility of PRD to establish application criteria of this irrigation water management strategy for banana cultivar BRS Princesa under semi-arid conditions of northeastern Minas Gerais State.

\section{Materials and Methods}

The experiment was carried out on-station in the semi-arid region of northeastern Minas Gerais $\left(15^{\circ} 48^{\prime} 09^{\prime \prime} \mathrm{S}, 43^{\circ} 18^{\prime} 32^{\prime \prime} \mathrm{W}\right.$, altitude $\left.537 \mathrm{~m}\right)$ with Aw climate to Köppen classification (Sá Junior et al., 2012). The soil is a Typical Hapludox with physical-hydraulic attributes (Table 1) with the Van Genuchten (1980) soil water retention curve parameters: $\alpha=0.6826 ; \mathrm{n}=1.3345$; $\mathrm{m}=0.2569$, saturation water content $=0.3200 \mathrm{~m}^{3} \mathrm{~m}^{-3}$ and residual water content $=0.2100 \mathrm{~m}^{3} \mathrm{~m}^{-3}$. The banana crop cultivar was BRS Princesa (Ledo et al., 2008) was planted at spacing $2.5 \mathrm{~m} \times 2.0 \mathrm{~m}$ in Mar 2013 and studied until the end of second growth seasons in Feb 2015. Irrigation consisted of a trickle system with two lateral lines per plant row with three drippers of $4 \mathrm{~L} \mathrm{~h}^{-1}$ per plant in each side. Each lateral line had a valve installed at its beginning to control the side to be irrigated. The banana crop was irrigated every two days based on the Penman-Monteith reference evapotranspiration equation and on banana crop coefficients (Allen et al., 1998). 
There was no irrigation in Nov and Dec, 2013, Dec 2014, and Jan 2015 due to rainfall (Figure 1).

The experiment followed a random block design, with five treatments or irrigation strategies and five replicates. Four treatments (irrigation strategies) consisted of applying $50 \%$ of the total calculated water irrigation depth (WID) at intervals $0,7,14$ and 21 days alternating the irrigated side of the plant row. The time interval 0 (zero) day means no alternating of the irrigated sides, that is, the plant row received $50 \%$ WID only on one side all time. One treatment consisted of WID irrigation on both sides of the plant row. Treatments were abbreviated to T1 (7 day-50\% WID), T2 (14 day-50\% WID), T3 (21 day-50 \% WID), T4 (one side $-50 \%$ WID) and T5 (full irrigation).

The soil water content (SWC) was evaluated every $3 \mathrm{~d}$ by frequency-domain reflectometry through capacitance probes at $0.30 \mathrm{~m}$ from the plant, $0.10 \mathrm{~m}$ from the dripper and at soil depth $0.25 \mathrm{~m}$ on each side of the plants in all plots. Data on SWC were used to obtain soil water availability (SWA) (equation 1).

$\mathrm{SWA}=\frac{\theta_{\mathrm{t}}-\theta_{\mathrm{wp}}}{\theta_{\mathrm{fc}}-\theta_{\mathrm{wp}}} \cdot 100$

where: $\theta_{\mathrm{t}}$ is SWC at time $\mathrm{t}$; $\theta_{\mathrm{fc}}$ is SWC at field capacity $(-10 \mathrm{kPa})$ and $\theta_{\mathrm{wp}}$ is SWC at wilting point $(-1500 \mathrm{kPa})$; unit $\theta$ is $\mathrm{cm}^{3} \mathrm{~cm}^{-3}$. The SWC was also evaluated during the second growth season at intervals of $1 \mathrm{~h}$, during $45 \mathrm{~d}$ in all treatments using an automatic station with a timedomain reflectometry reflectometer connected to multiplexers and probes $0.10 \mathrm{~m}$ long. The probes were installed in a two-dimensional plane from the plant along

Table 1 - Soil physical attributes at depth 0-0.4 m of the experimental area: sand, silt, clay, soil bulk density, soil moisture at potentials -10 and $-1500 \mathrm{kPa}$.

\begin{tabular}{|c|c|c|c|c|c|c|}
\hline Depth & Sand & Silt & Clay & bulk density & $\begin{array}{l}\text { Soil moisture } \\
-10 \mathrm{kPa}\end{array}$ & $\begin{array}{r}\left(\mathrm{cm}^{3} \mathrm{~cm}^{-3}\right) \\
-1500 \mathrm{kPa}\end{array}$ \\
\hline $\mathrm{m}$ & & $\mathrm{g} \mathrm{kg}^{-1}$ & & $\mathrm{~kg} \mathrm{dm}^{-3}$ & & \\
\hline $0.0-0.2$ & 483 & 234 & 283 & 1.71 & 0.2416 & 0.2116 \\
\hline $0.2-0.4$ & 444 & 263 & 293 & 1.65 & 0.2761 & 0.1877 \\
\hline
\end{tabular}

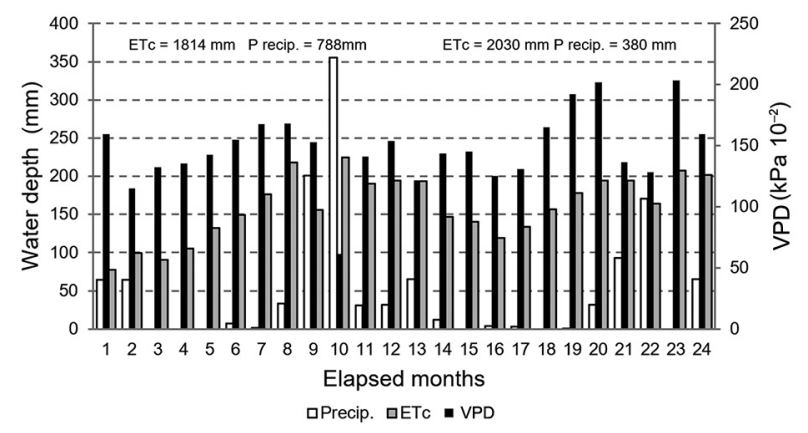

Figure 1 - Precipitation, evapotranspiration (ETC), water irrigation depth (WID) and vapor pressure deficit (VPD) during two growth seasons of banana cultivar BRS Princesa. the row at distances $0.25,0.50,0.75$ and $1.00 \mathrm{~m}$, and at depths $0.20,0.40,0.60$ and $0.80 \mathrm{~m}$ in each treatment.

Stomatal conductance was measured during the first and second growth seasons with an infrared gas analyzer (IRGA). At the end of the flowering period of the first growth season, roots from plants of all irrigation strategies were collected. Roots samples of $0.10 \times$ $0.10 \times 0.10 \mathrm{~m}\left(1,000 \mathrm{~cm}^{3}\right)$ were collected in a grid in the soil profile at four distances from the plant pseudo stem: $0.25,0.50,0.75$ and $1.0 \mathrm{~m}$ and at five depths: 0.05-0.15, $0.15-0.25,0.35-0.45,0.55-0.65$ and $0.75-0.85 \mathrm{~m}$. Roots were washed to separate the soil, and were then digitalized and subjected to the Rootedge software in order to determine root length (Kaspar and Ewing, 1997). Production variables: hand weight, bunch weight, number of hands and number of fruits per bunch were evaluated during the harvest period in both growth seasons. Crop water use efficiency (WUE) was considered as the ratio between crop yield $(\mathrm{kg})$ and crop evapotranspiration (mm) (Fan et al., 2011; Farias et al., 2008).

The analysis of variance of crop growth and yield data considered all five treatments (irrigation strategies) and used Scott-Knott mean tests at $5 \%$ probability. Data on SWC were analyzed by the split-plot scheme. The factors investigated were irrigation strategy (plot) and plant side status (irrigated and non-irrigated) (subplot).

\section{Results and Discussion}

Irrigation strategies (treatments) influenced the variables of fruit yield: bunch weight, hand weight and number of fruits per bunch and water use efficiency (WUE) in both growth seasons. T5 (full irrigated) provided the highest bunch and hand yields (Table 2). All irrigation strategies with WID reduction remained in the same group with no significant difference in bunch yield in the first growth season. T3 (21 day-50 \% WID) showed the smallest bunch and hand yield of all strategies in the second growth season (Table 2). The mean number of fruits per bunch did not differ among the treatments in the second growth season and were larger than in the first. The mean yields of bunches and hands of reduced WID treatments decreased between 12 and $16 \%$ compared with full irrigation in the first growth season. The reduction was $30 \%$ for T3 (21 day-50\% WID), and $7-11 \%$ for the other reduced WID treatments in the second growth season (Table 2). The greater yield reduction for T3 (21 day-50\% WID) in the second growth season was due to severe drought conditions with greater vapor pressure deficit, scarce rainfall (Figure 1) and lower SWA on the non-irrigated sides of plants (Table 3).

Irrigation strategies with WID reduction saved $784 \mathrm{~mm}$ of water in the first growth season and 1061 $\mathrm{mm}$ in the second with WUE increase of $74 \%$ and $78 \%$, respectively. Means of WUE did not differ statistically between WID reduction strategies (Table 2). The WUE mean values were smaller than the means obtained for banana cv. Prata Anã when irrigated with $50 \%$ re- 
Table 2 - Means of bunch and hand weights, number of fruits per bunch and water use efficiency (WUE) (kg mm-1) of banana cultivar BRS Pincesa submitted to $50 \%$ WID reduction for alternating frequencies of plant row side of: 0, 7, 14 and 21 days and full irrigation in the first and second growth seasons (GS).

\begin{tabular}{|c|c|c|c|c|c|c|c|c|}
\hline \multirow{3}{*}{ Treatment (Irrig. Strategy) } & \multirow{2}{*}{\multicolumn{2}{|c|}{$\begin{array}{c}\text { Yield of bunchs } \\
\text { t ha }^{-1}\end{array}$}} & \multirow{2}{*}{\multicolumn{2}{|c|}{$\begin{array}{c}\text { Yield of hands } \\
\text { t ha }^{-1}\end{array}$}} & \multirow{2}{*}{\multicolumn{2}{|c|}{ N. of fruits }} & \multirow{2}{*}{\multicolumn{2}{|c|}{$\frac{\text { WUE }}{\mathrm{kg} \mathrm{mm}^{-1}}$}} \\
\hline & & & & & & & & \\
\hline & GS 1 & GS 2 & GS 1 & GS 2 & GS 1 & GS 2 & GS 1 & GS 2 \\
\hline T5-Full irrigation & $34.69 \mathrm{a}$ & $41.86 a$ & $31.49 a$ & $37.82 \mathrm{a}$ & $101.9 \mathrm{a}$ & $161.7 \mathrm{a}$ & $24.23 b$ & $22.93 b$ \\
\hline T3-21 days-50 \%WID & $30.51 b$ & $32.08 \mathrm{c}$ & $27.84 b$ & $35.06 b$ & 99.9 a & $151.2 \mathrm{a}$ & $42.84 \mathrm{a}$ & 40.93 \\
\hline T4-0day-50 \%WID & $30.56 b$ & $37.87 b$ & $27.74 b$ & $34.87 b$ & $94.6 \mathrm{~b}$ & $150.2 \mathrm{a}$ & $42.68 \mathrm{a}$ & 40.64 \\
\hline T2-14days-50 \%WID & $30.02 b$ & $38.92 b$ & $27.45 b$ & $33.97 b$ & $92.0 \mathrm{~b}$ & $154.2 \mathrm{a}$ & $42.24 \mathrm{a}$ & 39.00 \\
\hline T1-7days-50 \%WID & $29.24 b$ & $38.58 \mathrm{~b}$ & $26.61 b$ & $28.75 c$ & $93.9 b$ & $143.4 \mathrm{a}$ & $40.95 a$ & 42.77 \\
\hline $\mathrm{CV}(\%)$ & \multicolumn{2}{|c|}{9} & \multicolumn{2}{|c|}{10} & \multicolumn{2}{|c|}{6} & \multicolumn{2}{|c|}{11} \\
\hline
\end{tabular}

Means followed by same letters in columns belong to the same group by Scott-Knott at $5 \%$ probability.

Table 3 - Means of soil water availability at 0-0.20 m depth for five irrigation strategies for 'BRS Princesa' in the first and second growth seasons (GS).

\begin{tabular}{|c|c|c|c|c|c|c|}
\hline \multirow{4}{*}{$\begin{array}{l}\text { Treatment } \\
\text { (Irrigation strategy) }\end{array}$} & \multicolumn{6}{|c|}{ Soil available water } \\
\hline & \multicolumn{6}{|c|}{$\longrightarrow$} \\
\hline & \multicolumn{2}{|c|}{ Both sides } & \multicolumn{2}{|c|}{ Non irrigated side } & \multicolumn{2}{|c|}{ Irrigated side } \\
\hline & GS 1 & GS 2 & GS 1 & GS 2 & GS 1 & GS 2 \\
\hline T5-Full irrigation & 107 & $148 \mathrm{a}$ & $80 a$ & $145 \mathrm{a}$ & $135 a$ & $151 \mathrm{a}$ \\
\hline T4-One-side irrigation & 77 & $75 a$ & $0 \mathrm{~d}$ & $0 \mathrm{~d}$ & $154 \mathrm{a}$ & $150 \mathrm{a}$ \\
\hline T1-7 days-50 \%WID & 61 & $51 \mathrm{~b}$ & $43 \mathrm{~b}$ & $45 \mathrm{~b}$ & $79 a$ & 58 a \\
\hline T2-14 days-50 \%WID & 44 & $48 \mathrm{~b}$ & $6 \mathrm{c}$ & $12 \mathrm{c}$ & $51 \mathrm{a}$ & $83 a$ \\
\hline T3-21 days-50 \%WID & 39 & $47 \mathrm{~b}$ & $7 \mathrm{c}$ & $39 \mathrm{~b}$ & $71 \mathrm{a}$ & $54 \mathrm{a}$ \\
\hline
\end{tabular}

Means followed by same letters in columns belong to the same group by ScottKnott test at $5 \%$ probability.

placement of crop evapotranspiration (Figueiredo et al., 2005). The yield found but the authors in this condition was almost half of the yield for full irrigation, differently from the results of this work. The yields obtained under WID reduction were reasonable if compared with the results reported by Arantes et al. (2016) and Ledo et al. (2008) under full irrigation in sub-humid and semi-arid conditions.

Treatment T5 (full irrigation) presented higher soil water availability (SWA) when compared to results for WID reduction strategies on both sides of the plant row (Table 3). Irrigation strategies with WID reduction resulted in SWA between 39 and $77 \%$ with soil water potentials less or equal to $-35 \mathrm{kPa}$ on both sides of the plant row. SWA on the irrigated side of the plant row ranged between 51 and $83 \%$ and on the non-irrigated side between 7 and $45 \%$, considering all irrigation strategies with WID reduction. Means of SWA were near $100 \%$ on the irrigated side and $0 \%$ on the non-irrigated side of $\mathrm{T} 4$ (one-side irrigation). The average moisture converted to soil water potential (Van Genuchten, 1980) on both sides of the plant row were close to the minimum potential (-35 $\mathrm{kPa}$ ) for optimal crop production, as reported by Ravi et al. (2013). Robinson and Bower (1987) observed that the soil water stress affected banana yield when soil potential reached $-25 \mathrm{kPa}$, which corresponded to $83 \%$ of SWA in this work.
Soil water content in T1 7 day-50 \% WID) required $6 \mathrm{~d}$ to reach $0 \%$ SWA on the non-irrigated side of the plant row. The reduction on root uptake rate in this strategy remained positive during $6 \mathrm{~d}$, as indicated by the moisture curve slope (Figure 2A). Soil water content in T2 (14 day-50\% WID) required $9 \mathrm{~d}$ to reach $0 \%$ SWA and remained below this condition during $5 \mathrm{~d}$ on the nonirrigated side of the plant row (Figure 2B). The uptake rate was positive during $11 \mathrm{~d}$ after irrigation and there was no extraction (null rate) on this side during $3 \mathrm{~d}$ until the alternating of irrigation side. Soil water content in T3 (21 day-50 \% WID) reached $0 \%$ SWA after $11 \mathrm{~d}$ and remained below this condition during $10 \mathrm{~d}$ on the nonirrigated side of the plant row (Figure 2C). The uptake rate was positive on this side during $11 \mathrm{~d}$ after irrigation and no root uptake occurred until the alternating of irrigation side. The moisture in $\mathrm{T} 4$ (one-side irrigation) remained below the $0 \%$ SWA without root uptake on the non-irrigated side during all crop seasons (Figure 2D).

The frequency reduction of alternating sides increased the period without root uptake at the layer $0-0.30 \mathrm{~m}$ on the non-irrigated side of the plant row. The main reason for the decrease of root uptake with soil moisture is the reduction of gradients of water potential between soil and roots or high demand for transpiration in the shoot (high vapor pressure deficit) and relative low flow from roots due to low soil water potential (Jackson et al., 2000). Only T1 (7 day-50 \% WID) did not compromise water uptake on both sides of the plant row. All other strategies interrupted root uptake on the dry side during at least $3 \mathrm{~d}$.

The root uptake rate was higher for strategy T3 than $\mathrm{T} 1, \mathrm{~T} 2$, and $\mathrm{T} 5$ on the irrigated side of plant row. This indicates possible adaptation of active roots of the irrigated side of plants to compensate the uptake loss of the non-irrigated side. Root distribution may be an explanation as it was more uniform at soil depth for strategies T1 and T5 with 30 to $38 \%$ of roots linearly distributed between $0.20 \mathrm{~m}$ and $0.80 \mathrm{~m}$ depths (Figure 3). Eighty-five percent of roots was found at 0-0.20 m depths of T3 (21 day-50\% WID), indicating that SWA was not enough to supply water to roots below this depth (Turner et al., 2007). 

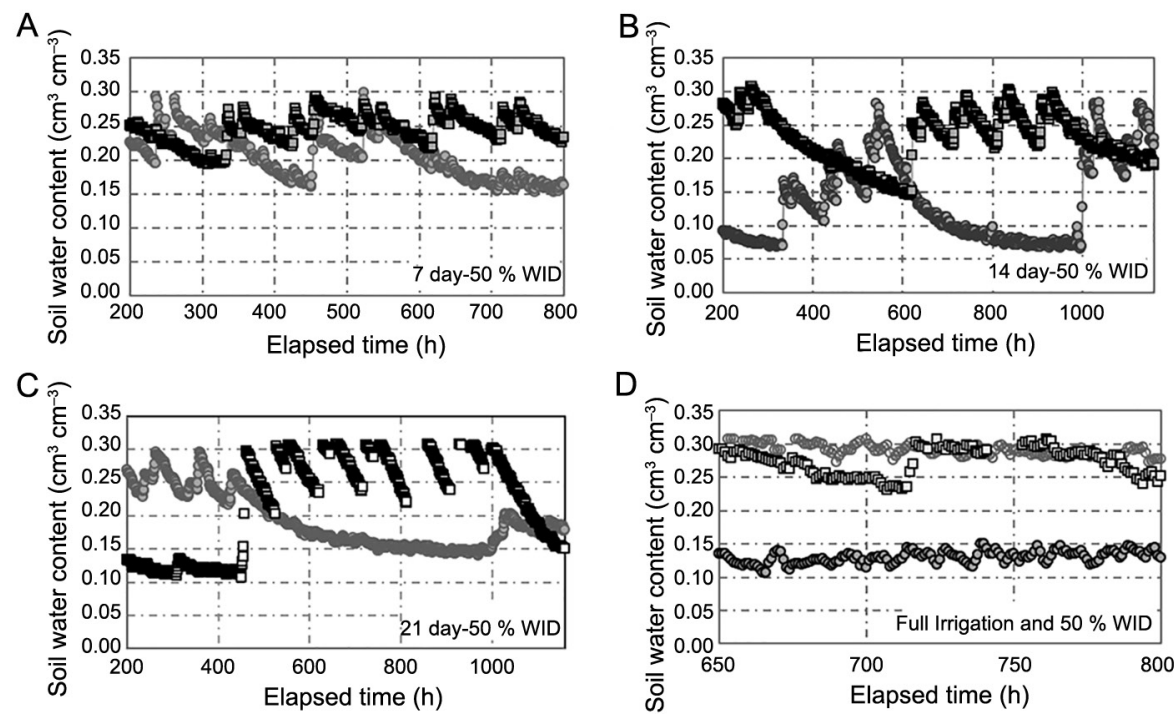

Figure 2 - Soil water content according to time for five irrigation strategies: (A) 7 days - 50 \% WID strategy, (B) 14 days - 50 \% WID strategy, (C) 21 days - $50 \%$ WID strategy and (D) one-side irrigation and full irrigation.

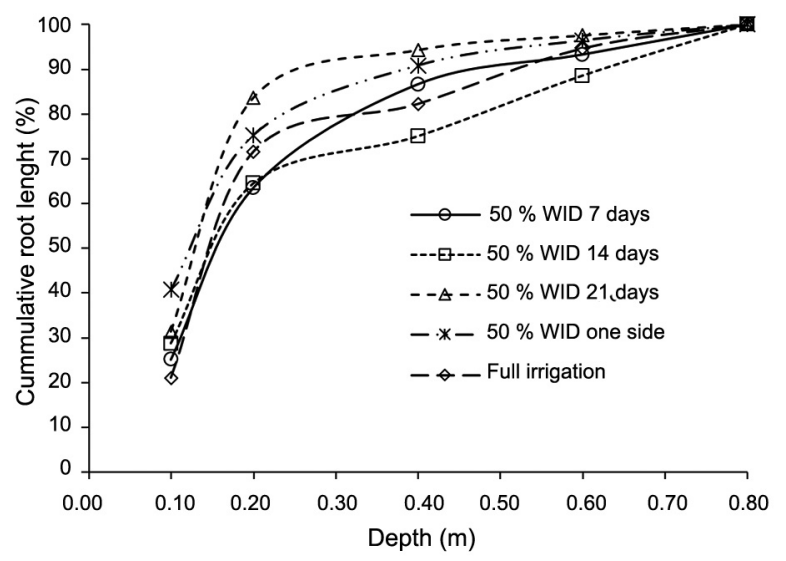

Figure 3 - Cumulative root length (\%) of banana cultivar BRS Princesa according to soil depth for five irrigation strategies $(50$ \%WID 7 days, 50 \%WID 14 days, $50 \%$ WID 21 days, $50 \%$ WID oneside irrigation and Full irrigation).

Treatments with WID reduction did not influence stomatal conductance (gs) (Table 4) under vapor pressure deficit (VPD) from 1.25 to $1.58 \mathrm{kPa}$ during the first crop season (Figure 1). The smaller crop evapotranspiration (Figure 1) is related to smaller potential gradient between leaf and air because of lower VPD (below 1.58 $\mathrm{kPa}$ ). These results show that stomatal conductance of cultivar BRS Princesa is not sensitive to soil water stress intensity, under mild climate conditions. Donato et al. (2015) and Coelho et al. (2015) obtained similar results and verified that cultivar BRS Princesa showed the lowest yield increase rate with water irrigation depth when compared to cultivars: Prata Anã, Grand Naine and Platina.
Table 4 - Stomatal conductance, gs $\left(\mathrm{mmol} \mathrm{m}^{-2} \mathrm{~s}^{-1}\right)$ for five treatments (irrigation strategies) during different periods (days after application - DAB) of the first and the second growth seasons of banana cultivar BRS Princesa.

\begin{tabular}{|c|c|c|c|c|c|c|}
\hline \multicolumn{7}{|c|}{ Growth Season 1} \\
\hline & T1(7 days) & T2(14 days & T3(21 days & T4(one-side) & T5 & VPD \\
\hline DAB & 50 \%WID & $50 \%$ WID & $50 \%$ WID & 50 \%WID & Full irrig. & $(\mathrm{kPa})$ \\
\hline 132 & 430 & 340 & 350 & 320 & 390 & 1.28 \\
\hline 162 & 370 & 450 & 390 & 370 & 440 & 1.46 \\
\hline 189 & 160 & 160 & 160 & 160 & 150 & 1.58 \\
\hline 253 & 300 & 330 & 330 & 290 & 340 & 1.25 \\
\hline \multicolumn{7}{|c|}{ Growth Season 2} \\
\hline 575 & $278 b$ & $184 \mathrm{c}$ & $56 \mathrm{e}$ & $149 \mathrm{~d}$ & $523 a$ & 1.92 \\
\hline 576 & $312 b$ & $117 c$ & $36 \mathrm{~d}$ & $216 c$ & $477 a$ & 2.22 \\
\hline 595 & $262 \mathrm{a}$ & $139 b$ & $129 b$ & $91 \mathrm{~b}$ & $251 \mathrm{a}$ & 2.25 \\
\hline
\end{tabular}

Means followed by different low case letters in the same line differ by the Scott-Knott test at $5 \%$ probability. ${ }^{*}$ No changes on the irrigated side.

Strategies for soil water reduction affected stomatal conductance when VPD ranged from 1.92 to $2.25 \mathrm{kPa}$ (Table 4), under a larger evapotranspiration (Figure 1). Stomatal conductance reduced with the increase of soil water deficit on the non-irrigated side of the plant row under these VPD conditions. The difference between gs for T5 (full irrigation) and for WID reduction treatments, mainly T2, T3 and T4, is due to shoot physiological regulation (Zegbe et al., 2006). This is because dry roots send a chemical signal (abscisic acid-ABA) to shoot (Davies and Zang, 1991; Kang and Zang, 2004) to regulate stomata aperture thus preventing excessive shoot dehydration stress (Davies et al., 2005). The largest gs of T1 (7 day - $50 \%$ WID) among the treatments with WID reduction is due 
to the larger levels of SWA on both sides of the plant row, which are enough to keep water flowing from roots to shoot and respond to potential gradient between them under larger VPD conditions. The soil moisture on both sides of the plant rows for the other treatments with WID reduction, mainly $\mathrm{T} 2$ and $\mathrm{T} 3$, was not enough to respond to potential gradients and led to more intense root-shoot signaling and larger stomata closure under larger VPD conditions. The plant stress was near severe levels only for T3 (21 day-50\% WID), since gs were close to $100 \mathrm{mmol} \mathrm{m} \mathrm{m} \mathrm{s}^{-1}$, which is a severe stress level for plants (Flexas et al., 2006).

\section{Conclusions}

The yield decrease in banana BRS Princesa by partial root-zone drying strategies is due to the reduction in root uptake rate, which is related to vapor pressure deficit and soil water availability on both sides of the plant rows.

The increase in the interval of alternating the irrigated sides reduces time of simultaneous root water uptake on both sides of the plant rows.

Cultivar BRS Princesa shows low physiological regulation under $50 \%$ reduction of soil water and under vapor pressure deficit up to $1.67 \mathrm{kPa}$.

Partial root-zone drying strategies with reduction of $50 \%$ WID and alternating irrigated plant row sides every $7 \mathrm{~d}$ allow an increase of $78 \%$ in water use efficiency and reduction of up to $8 \%$ in yields.

\section{Authors' Contributions}

Conceptualization: Coelho, E.F.; Oliveira, P.M. Data acquisition: Coelho, E.F.; Donato, S.L.R.; Santos, M.R. Data analysis: Coelho, E.F.; Donato, S.L.R.; Santos, M.R.; Cruz, J.L.; Castricini, A. Methodology: Donato, S.; Santos, M.R. Writing and editing: Coelho, E.F.; Donato, S.L.R.; Santos, M.R.; Cruz, J.L.; Castricini, A.

\section{References}

Allen, R.G.; Pereira, L.S.; Raes, D.; Smith, M. 1998. Crop Evapotranspiration: Guidelines for Computing Crop Water Requirements. FAO, Rome, Italy. (FAO Irrigation and Drainage Paper, 56).

Arantes, A.D.; Donato, S.L.R.; Siqueira, D.L.D.; Coelho, E.F.; Silva, T.S. 2016. Gas exchange in different varieties of banana 'Prata' in semi-arid environment. Revista Brasileira de Fruticultura 38: 1-12.

Coelho, E.F.; Silva, A.J.P.; Donato, S.L.R.; Santana Júnior, E.B.; Oliveira, P.M. 2015. Trickle irrigation systems and irrigation water management in banana. Informe Agropecuário 36: 62-73 (in Portuguese, with abstract in English).

Davies, W.J.; Kudoyarova, G.; Hartung, W. 2005. Long-distance ABA signaling and its relation to other signaling pathways in the detection of soil drying and the mediation of the plant's response to drought. Journal of Plant Growth Regulation 24: 285-295.
Davies, W.J.; Zhang, J.H. 1991. Root signals and the regulation of growth and development of plants in drying soil. Annual Review of Plant Physiology and Plant Molecular Biology 42: 55-76.

Davies, W.J.; Zhang, J.; Yang, J.; Dodd, L.C. 2011. Foresight Project on Global Food and Farming Futures: novel crop science to improve yield and resource use efficiency in water-limited agriculture. Journal of Agricultural Science 149: 123-131.

Dodd, I.C. 2009. Rhizosphere manipulations to maximize 'crop per drop' during deficit irrigation. Journal of Experimental Botany 60: 2454-2459.

Donato, S.L.R.; Coelho, E.F.; Santos, M.R.; Arantes, A.M.; Rodrigues, M.G.V. 2015. Water use efficiency in banana. Informe Agropecuário 36: 46-61 (in Portuguese, with abstract in English).

Fan, M.; Shen, J.; Yuan, L.; Jiang, R.; Chen, X.; Davies, W.J.; Zhang, F. 2011. Improving crop productivity and resource use efficiency to ensure food security and environmental quality in China. Journal of Experimental Botany 63: 13-24.

Farias, C.H.A.; Fernandes, P.D.; Dantas Neto, J.; Gheyi, H.R. 2008. Water use efficiency in sugarcane crop under different depths of irrigation and zinc doses in coastal region of Paraíba, Brazil. Engenharia Agrícola 28: 494-506 (in Portuguese, with abstract in English).

Fereres, E.; Soriano, M.A. 2007. Deficit irrigation for reducing agricultural water use. Journal of Experimental Botany 158: 147-159.

Figueiredo, F.P.; Oliveira, F.G.; Maia, V.M.; Costa, L.C. 2005. Influence of irrigation depths on energy efficiency, water use and productivity of banana plant 'Prata Anã'. Revista Brasileira de Agrometeorologia 13: 53-58 (in Portuguese, with abstract in English).

Flexas, J.; Bota, J.; Galmés, J.; Medrado, H.; Ribas-Carbó, M. 2006. Keeping a positive carbon balance under adverse conditions: responses of photosynthesis and respiration to water stress. Physiologia Plantarum 127: 343-352.

Kang, S.; Hu, S.; Goodwin, I.; Peter, J. 2002. Soil water distribution, water and yield response to partial root zone drying under a shallow groundwater table condition in a pear orchard. Scientia Horticulturae 92: 277-291.

Kang, S.Z.; Zhang, J.H. 2004. Controlled alternate partial rootzone irrigation: its physiological consequences and impact on water use efficiency. Journal of Experimental Botany 55: 24372446.

Kaspar, T.C.; Ewing, R.P. 1997. Rootedge: software for measuring root length from desktop scanner images. Agronomy Journal 89: 932-940.

Ledo, A.S.; Silva Júnior, J.F.; Ledo, C.A.S.; Silva, S.O. 2008. Evaluation of banana genotypes in the low São Francisco river basin, Sergipe, Brazil. Revista Brasileira de Fruticultura 30: 691-695 (in Portuguese, with abstract in English).

Ravi, Y.; Uma, S.; Vaganan, M.M.; Mustafa, M.M. 2013. Phenotyping bananas for drought resistance. Frontiers in Physiology 4: 1-15.

Robinson, J.C.; Albert, A.J. 1986. Growth and yield responses of banana (cultivar 'williams') to drip irrigation under drought and normal rainfall conditions in the subtropics. Scientia Horticulturae 30: 187-202. 
Robinson, J.C.; Bower, J.P. 1987. Transpiration characteristics of banana leaves (cultivar 'Williams') in response to progressive depletion of available soil moisture. Scientia Horticulturae 30: 289-300.

Sadras, V.O. 2009. Does partial root-zone drying improve irrigation water productivity in the field? A meta-analysis. Irrigation Science 27: 183-190.

Sampaio, A.H.R.; Coelho Filho, M.A.; Coelho, E.F.; Daniel, R. 2014. Physiological indicators of 'Thahiti' acid lime under regulated deficit irrigation and partial rootzone drying irrigation. Irriga 19: 292-301 (in Portuguese, with abstract in English).

Santos, M.R.; Donato, S.L.R.; Coelho, E.F.; Cotrim Junior, P.R.F.; Castro, I.N. 2016. Irrigation deficit strategies on physiological and productive parameters of 'Tommy Atkins' mango. Revista Caatinga 29: 173-182.

Santos, M.R.; Neves. B.R.; Silva, B.L.; Donato, S.L.R. 2015. Yield, water use efficiency and physiological characteristic of "Tommy Atkins" mango under partial rootzone drying irrigation system. Journal of Water Resource and Protection 7: 1029-1037.
Sivakumar, M.V.K.; Das, H.P.; Brunini, O. 2005. Impacts of present and future climate variability and change on agriculture and forestry in the arid and semi-arid tropics. Cimate Change 70: 31-72.

Turner, D.W.; Fortescue, J.A.; Thomas, D.S. 2007. Environmental physiology of the bananas (Musa spp.). Brazilian Journal of Plant Physiology 19: 463-484.

Van Genuchten, M.T. 1980. A closed-form equation for predicting the hydraulic conductivity of unsaturated soils. Soil Science Society of America Journal 44: 892-898.

Zegbe, J.A.; Behboudian, M.H.; Clothier, B.E. 2006. Responses of 'Petopride' processing tomato to partial rootzone drying at different phenological stages. Irrigation Science 24: 203-210. 